\title{
KOMUNIKASI KELOMPOK DALAM MEMBENTUK KONSEP DIRI PADA KOMUNITAS "SERIBU GURU ACEH" DI BANDA ACEH
}

\author{
Saufa Yardha \\ Program Studi S1 IImu Komunikasi Universitas Syiah Kuala \\ Kopelma Darussalam, Syiah Kuala, Kota Banda Aceh, \\ Aceh 24415 Indonesia \\ Email: saufayardha1203@gmail.com
}

\begin{abstract}
Abstrak
Komunikasi kelompok dalam membentuk konsep diri pada Komunitas Seribu Guru Aceh, tujuan dari penelitian ini untuk mengetahui sejauh mana komunikasi kelompok yang terjalin di antara sesama anggota, volunteer, dalam Komunitas Seribu Guru Aceh dan untuk mengetahui bagaimana komunikasi kelompok yang terjadi pada Komunitas Seribu Guru Aceh dalam membentuk konsep diri para anggotanya. Pendekatan yang digunakan dalam penelitian ini adalah pendekatan kualitatif. Jenis penelitian yang digunakan yaitu jenis penelitian deskriptif. Teori yang digunakan yaitu teori looking glass self, perkembangan konsep diri. Subjek dalam penelitian ini adalah anggota Komunitas Seribu Guru Aceh yang berpartisipasi secara langsung dalam kegiatan komunitas, penelitian ini menggunakan teknik wawancara, observasi dan dokumentasi, dalam teknik pengumpulan data serta teknik penarikan sampel yang digunakan adalah snowball sampling yaitu sumber data yang pada awalnya sedikit, lama-lama menjadi besar dan sampai jenuh. Melalui penelitian pada anggota dan volunteer Komunitas Seribu Guru Aceh, di peroleh hasil bahwa komunikasi yang terjadi dan terjalin antara sesama anggota dan volunteer berjalan dengan baik, komunikasi kelompok dalam komunitas dapat membentuk konsep diri anggotnya serta konsep dirijuga mengarah kepada konsep diri positif yaitu, meningkatkan rasa kepedulian, meningkatkan rasa percaya diri akan kemampuan diri yang dimiliki, memiliki banyak teman, menjadi lebih menghargai orang lain dan meningkatkan kemampuan berkomunkasi dengan baik. Yang terpenting bahwa melalui komunitas Seribu Guru Aceh seluruh anggota mempunyai kemampuan, berbagi ilmu dan pengalaman, kepada anak-anak yang membutuhkan, terutama anak-anak yang berada di daerah pedalaman dalam mengecap pendidikan.
\end{abstract}

Kata Kunci: Komunikasi Kelompok, Konsep Diri, Pembentukan Konsep Diri 


\section{Pendahuluan}

Aceh, saat ini telah banyak lahir kelompok-kelompok atau yang disebut dengan komunitas. Komunitas dengan berbagai tujuan, visi misi dan konsep yang berbeda, salah satunya, komunitas yang bergerak dalam bidang pendidikan yaitu Komunitas Seribu Guru Aceh. Komunitas Seribu Guru bukan berarti komunitas yang beranggotakan seribu orang guru akan tetapi nama Seribu Guru dimaksudkan bahwa semua dapat menjadi pendidik tanpa harus menyandang gelar guru. Awal terbentuknya Komunitas Seribu Guru Aceh ini yaitu karena terdapatnya pemuda-pemuda Aceh yang peduli terhadap pendidikan, mereka beranjak bergabung dengan Komunitas Seribu Guru pusat. Pada tanggal 25 Agustus Tahun 2015 yang lalu Komunitas Seribu Guru Aceh diresmikan oleh founder Komunitas Seribu Guru pusat. Saat ini Komunitas Seribu Guru sudah tersebar di 35 regional di seluruh Indonesia.

Komunitas Seribu Guru Aceh, yaitu Guru terdiri dari empat huruf namun di dalamnya terdapat pengorbanan, air mata, pengabdian dan kebahagiaan. Kegiatan yang telah Komunitas Seribu Guru Aceh lakukan yaitu kegiatan travelling dan teaching, kegiatan ini dilakukan selama dua hari di pedalaman dan sekolah yang telah ditentukan oleh panitia pelaksana, yaitu pada hari sabtu dan minggu.

Founder Seribu Guru pusat mengatakan bahwa mereka ingin merubah pola pikir pemuda yang banyak menghabiskan waktu dengan jalan-jalan namun tidak bermanfaat, komunitas ini jalan-jalan sambil mengajarkan ilmu pengetahuan.

Pedalaman dan di perbatasan pendidikan sangat mahal. Gedung sekolah memang baik, namun kualitas pendidikan sangat berbeda dengan kualitas pendidikan dengan kota lainnya. Komunitas ini tidak memiliki sangkut paut apapun dengan dunia politik maupun dengan pemerintah, mereka mengerjakannya secara sukarela, banyak bantuan yang diperoleh dari sponsor dan donatur atas usaha tim masing-masing. Hal lain yang menarik dalam komunitas ini yaitu anggotanya terdiri dari semua kalangan profesi mulai dari 
Mahasiswa, Guru, Fotografer, Aktivis, Pekerja Swasta dan Dokter (tulongaceh.weebly.com, 2015).

Komunitas Seribu Guru Aceh melakukan interaksi dengan anggota dan volunteernya dalam semua kegiatan dan pertemuan yang dilakukan, mengingat bahwa komunitas ini baru di Aceh dan tentunya peminat untuk menjadi volunteer juga sudah terlihat dari antusias para calon volunteer dari berbagai kalangan profesinya tentunya akan menghasilkan atau merasakan suatu konsep diri yang berbeda pada setiap anggota, volunteer, serta kegiatan komunitas ini terbilang unik yaitu jalan-jalan sambil mengajarkan ilmu yang mereka miliki kepada anak-anak di pedalaman dan di pelosok negeri, tentunya dengan daerah yang tidak pernah terjangkau ataupun luput dari perhatian pemerintah atau pemuda setempat. Komunitas ini pun terbentuk dari anak-anak muda yang memiliki jiwa sosial sangat tinggi dalam dunia pendidikan.

Bagaimana komunikasi kelompok dibangun dalam membentuk konsep diri anggota agar semua kegiatan komunitas dapat berjalan dan anggota juga mendapatkan gambaran mengenai dirinya atau disebut konsep diri. Atas dasar pertimbangan dari kegiatan atau program yang telah mereka laksanakan yaitu kegiatan travelling and teaching yang di mana kegiatan ini dilaksanakan selama dua hari. Untuk mengetahui lebih jelas mengenai komunikasi kelompok dalam membentuk konsep diri pada Komunitas Seribu Guru Aceh. Dan mengangkat judul Komunikasi Kelompok Dalam Membentuk Konsep Diri pada Komunitas "Seribu Guru Aceh" di Banda Aceh. Untuk penulis teliti lebih lanjut.

\section{Landasan Teori}

Penelitian ini menggunakan teori Looking glass self Menurut Charles Horton Cooley, kita melakukannya dengan membayangkan diri kita sebagai orang lain dalam benak kita. Konsep diri menurut Cooley disebut looking-glass self (diri cermin), seakan-akan kita menaruh cermin di depan kita. Pertama, kita membayangkan bagaimana kita tampak pada orang lain, kita melihat sekilas diri kita seperti dalam cermin. Misalnya, kita merasa wajah kita jelek. Kedua, kita membayangkan bagaimana orang lain menilai penampilan kita. Kita pikir 
mereka menganggap kita tidak menarik. Ketiga, kita mengalami perasaan bangga atau kecewa, orang mungkin merasa sedih atau malu Vander Zanden (1975:79) dalam Rakhmat, 2007:99). Dengan mengamati diri kita, sampailah kita pada gambaran dan penilaian diri kita, ini disebut konsep diri. Menurut William D. Brooks mendefinisikan konsep diri sebagai pandangan dan perasaan kita tentang diri kita.

Menurut William D. Brooks dan Philip Emmert bahwa tanda-tanda konsep diri terdiri dari dua yaitu konsep diri positif dan negatif. Konsep diri positif ditandai dengan lima hal di antaranya, yakin akan mampu mengatasi masalah, merasa setara dengan orang lain, menerima pujian tanpa rasa malu, menyadari bahwa setiap orang mempunyai berbagai perasaan, keinginan dan perilaku yang tidak seluruhnya disetujui oleh masyarakat, yang terakhir ia mampu memperbaiki dirinya. Adapun konsep diri yang negatif yaitu, peka pada kritik, responsif sekali atas pujian, cenderung merasa tidak disenangi oleh orang lain, dan bersikap pesimis terhadap kompetisi. (Rakhmat, 2007:105).

\section{Metode Penelitian}

Pendekatan penelitian yang dilakukan dalam penelitian ini adalah pendekatan kualitatif. Pendekatan kualitatif menurut Kriyantono (2006:56) adalah penelitian yang menjelaskan fenomena dengan sedalam-dalamnya. Penelitian ini mengutamakan besarnya populasi atau sampling bahkan populasi atau samplingnya sangat terbatas. Jika data yang terkumpul sudah mendalam dan bisa menjelaskan fenomena yang diteliti, maka tidak perlu mencari sampling lainnya. Di sini yang lebih ditekankan adalah persoalan kedalaman (kualitas) data bukan banyáknya (kuantitas) data. Dalam penelitian ini peneliti hanya ingin mengetahui gambaran sejauh mana komunikasi kelompok yang terjalin di antara sesama anggota dan volunteer dalam Komunitas Seribu Guru Aceh dan bagaimana komunikasi kelompok yang terjadi pada Komunitas Seribu Guru Aceh dalam membentuk konsep diri para anggotanya.

Penelitian ini termasuk ke dalam jenis penelitian deskriptif yang bertujuan membuat deskripsi secara sistematis, faktual, dan akurat tentang fakta-fakta dan sifat-sifat populasi 
atau objek tertentu. Peneliti sudah mempunyai konsep dan kerangka konseptual. Melalui kerangka konseptual (landasan teori), peneliti melakukan operasionalisasi konsep yang akan menghasilkan variabel beserta indikatornya. Penelitian ini untuk menggambarkan realitas yang sedang terjadi tanpa menjelaskan hubungan antar variabel. Fenomena yang akan dijelaskan yaitu sejauh mana komunikasi kelompok yang terjalin di antara sesama anggota dan volunteer dalam Komunitas Seribu Guru Aceh dan bagaimana komunikasi kelompok yang terjadi pada Komunitas Seribu Guru Aceh dalam membentuk konsep diri para anggotanya.

Dalam penelitian ini peneliti menggunakan teknik penarikan sampel menggunakan snowball sampling. Dalam snowball sampling ini kita mulai dengan kelompok kecil yang diminta untuk menunjukkan kawan masing-masing. Kemudian kawan-kawan ini diminta untuk menunjuk kawan masing-masing dan begitu seterusnya sehingga kelompok itu senantiasa bertambah besar. Sampling ini dipilih bila kita ingin meneliti hubungan antar manusia dalam kelompok yang ada, (Taher, 2009:69). Dan menurut Sugiono (2015:54) Snowball Sampling adalah teknik pengambilan sampel sumber data, yang pada awalnya jumlahnya sedikit, lama-lama menjadi besar.

Metode pengumpulan data adalah teknik atau cara-cara yang dapat digunakan peneliti untuk mengumpulkan data Kriyantono (2006). Dalam penelitian ini peneliti menggunakan teknik pengumpulan data wawancara, observasi partisipatif pasif dan dokumentasi.

Moleong (2000 dalam Kriyantono, 2006:167) mendefinisikan analisa data sebagai proses mengorganisasikan dan mengurutkan data kedalam pola, kategori, dan satuan uraian dasar sehingga dapat ditemukan tema dan dapat dirumuskan hipotesis kerja seperti yang di sarankan oleh data. Menurut Miles dan Huberman (1989 dalam Ali, 2014) data kualitatif, bersifat membumi, kaya akan deskripsi, dan mampu menjelaskan tentang proses. Agar data itu memberi makna, dalam analisis yang dilakukan ditempuh langkah-langkah sebagai berikut. 
a. Reduksi data peneliti melakukan seleksi data, memfokuskan data pada permasalahan yang dikaji.

b. Display data adalah langkah mengorganisasi data dalam suatu tatanan informasi yang padat atau kaya makna sehingga dapat dengan mudah dibuat kesimpulan. Displai data biasanya dibuat dalam cerita atau teks.

c. Kesimpulan dan verifikasi merupakan langkah terakhir menarik kesimpulan dan melakukan verifikasi terhadap kesimpulan yang dibuat.

\section{Hasil Penelitian}

Hasil penelitian ini diperoleh berdasarkan wawancara secara terstruktur, observasi partisipatif pasif, dokumentasi peneliti terhadap 15 informan penelitian yang dilakukan selama kurun waktu satu minggu yaitu mulai tanggal 7 Mei 2016 hingga 13 Mei 2016. Namun peneliti juga melakukan observasi partisipatif pasif awal dan mewawancarai anggota Komunitas Seribu Guru Aceh pada bulan April sampai bulan Mei 2016, data yang diperoleh selama penelitian dianalisis dan hasil penelitian diuraikan menjadi berbagai pembahasan yaitu komunikasi kelompok yang terjalin di antara sesama anggota dan volunteer dan komunikasi kelompok dalam membentuk konsep diri para anggotanya di Komunitas Seribu Guru Regional Aceh.

Hasil penelitian yang di peroleh dalam penelitian ini yaitu komunikasi yang terjadi dan terjalin antara sesama anggota dan volunteerberjalan dengan baik, anggota dan volunteer sudah memiliki kedekatan hal ini juga didukung dengan beberapa faktor yaitu komunikasi, menjaga kepercayaan sesama tim, saling menerima kekurangan anggota masing-masing, konflik, penyesuian diri dan berbagi informasi lainya. Sedangkan komunikasi kelompok dalam komunitas dapat membentuk konsep diri anggotnya, konsep diri juga mengarah kepada konsep diri positif yaitu, meningkatkan rasa kepedulian, meningkatkan rasa percaya diri akan kemampuan diri yang dimiliki, memiliki banyak teman, menjadi lebih menghargai orang lain dan meningkatkan kemampuan berkomunkasi dengan baik. Yang terpenting bahwa melalui komunitas Seribu Guru Aceh seluruh anggota 
mempunyai kemampuan, berbagi ilmu dan pengalaman, kepada anak-anak yang membutuhkan, terutama anak-anak yang berada didaerah pedalaman dalam mengecap pendidikan.

\section{Komunikasi kelompok yang terjalin di Komunitas Seribu Guru Aceh}

Dari hasil wawancara yang telah dilakukan, peneliti mendapat respon yang baik dari informan penelitian, mengenai komunikasi kelompok yang terjalin. Para anggota dan volunteer komunitas umumnya memberikan tanggapan yang positif dan hampir keseluruhan mengatakan hal yang sama mengenai komunikasi yang terjalin selama ini, dan Komunikasi kelompok dalam komunitas ini dilakukan dengan cara tatap muka baik dalam agenda rapat maupun silaturahmi antara anggota dan melalui sosial media.

berikut penuturan beberapa narasumber:

"Bagus, semuanya ramah-ramah, dekat dan kita semua mudah dalam berbaurnya" (Yetriani, 12 Mei 2016).

"Kita di Seribu Guru ada beberapa kali rapat atau silaturahmi tetap berjalan dan memperbolehkan bahwa mengenai TNT boleh sebulan sekali atau dua bulan sekali untuk mempersiapkan TNT tidak bisa seminggu mau acara namun, harus sebulan, karena sebulan itu kita selalu dan sering bertemu maka dari pertemuan itu kita makin dekat, di media sosial juga kita memiliki group jadi komunikasinya tetap berjalan dan aktif. "(Fidya Rizkina, 9 Mei 2016).

"Senang asik bukan hanya Traveling kedaerah lain yang belum pernah orang pergi dan masih ada sekolah di Aceh yang tidak layak pakai, masih ada anak yang tidak pakai sepatu, masih ada anak tidak memiliki baju sekolah na itu yang harusnya diperhatikan, kita tidak menjudge pemerintah karena kita sebagai anak muda bukan saya meminta kepada negara apa yang bisa negara berikan kepada kita namun sebenarnya apa yang kita bisa berikan kepada negara." (Erlina Mariana, 7 Mei 2016).

Beberapa informan penelitian merasa bahwa kedekatan mereka sudah seperti keluarga, sesama anggota, dan volunteer memiliki faktor penting yaitu. 


\section{a. Komunikasi}

Bahwa komunikasi merupakan salah satu aktivitas yang sangat fundamental dalam kehidupan manusia, serta berkomunikasi dengan baik akan memberi pengaruh langsung pada struktur keseimbangan sesorang (Cangara, 2011: 2) berkomunikasi yang baik, maka pesan yang ingin disampaikan dapat diterima dengan baik pula, dalam Komunitas Seribu Guru Aceh ini juga komunikasi yang menjadi faktor utama dalam mencapai tujuan yang dinginkan,

berikut penuturan beberapa narsumber:

"Komunikasi, tanpa komunikasi itu kita sering terjadi kesalahpahaman, untuk dapat mengurangi hal tersebut, maka harus berkomunikasi dengan baik dan cara penyampainya juga harus baik dan diperhatikan" (Khairul Bariah, 13 Mei 2016) "Komunikasi merupakan faktor utama, saling menerima kekurangan anggota kelompok". (Rivana Amelia,12 Mei 2016).

\section{b. Saling menerima kekurangan anggota kelompok masing-masing}

Setiap individu tentunya mempunyai kelebihan dan kekuranganya masing-masing tergantung pada individu tersebut bagaimana menyikapi dan mengetahui kekurangan dan kelebihan yang ada pada dirinya, di komunitas Seribu Guru Aceh bahwa keseluruhan anggota menerima kekurangan anggota kelompoknya dan mencoba untuk saling melengkapi dan membantu individu-individu dalam menyelesaikan tugasnya.

Berikut penuturan salah satu narasumber:

Awalnya tidak susah, ada yang mahasiswa ada yang sudah bekerja, komunikasi, kalau mau tugas rima dengan baik ya komunikasi yang baik, kalau misalnya rima tidak bisa menyelesaikan suatu pekerja bisa meminta tolong kepada yang lain. (Rima Melati Ujung, 13 Mei 2016)

\section{c. Menjaga kepercayaan antar sesama anggota dalam tim}

Faktor penting lainya dalam komunitas ini agar tim tetap kompak menjaga kepercaaan antar sesama anggota dalam tim, saling menyemangati dan percaya bahwa setiap individu yang diberikan tugas padanya, bahwa individu tersebut mampu untuk 
melaksankannya, jika pun mengalami masalah atau kendala dalam proses penyelesaianya akan didiskusikan dan dibawah ke forum dalam komunitas ini. Berikut penuturan beberapa narasumber:

"Kebersamaan kekeluargaan susah sama-sama dan konflik juga dapat membuat hubungan antar anggota semakin erat". (Andri Munazir,11 Mei 2016).

"Untuk berbagi pengalaman yaitu orang yang care, mau menjadi pendengar yang baik dan bisa tukar pikiran timbal balik dan orang yang tidak egois yang tidak hanya didengarkan" (Sayed Rustia, 10 Mei 2016).

Kebersamaan, kemudian karena ada konflik yang membuat kita bersatu, kadangkadang rasa lelah, capek sama-sama itu juga membuat seperti keluarga walaupun kita berbedaa karakter dari latar belakang yang berbeda, sudah mersakan seperti rumah sendiri. (Erlina Mariana, 7 Mei 2016).

\section{d. Membagikan informasi dan Penyesuaian diri}

Anggota dari setiap Komunitas Seribu Guru Aceh, membagikan informasi mengenai informasi dari komunitas pusat, lowongan pekerjaan, kerja sama yang mereka lakukan dimedia sosial agar tetap menjaga silaturahmi anggota, hal lainya yang juga penting yaitu mengenai penyesuaian diri, penyesuaian diri dalam komunitas ini tidak sulit, sebagai anggota yang baru mudah sekali untuk berbaur, karena semua anggota menerima dengan tangan terbuka. Namun etika dan sopan santun tetap harus diperhatikan, penyesuaian diri juga tidak memerlukan cara khusus untuk bergabung, sesuai dengan diri pribadi masingmasing.

Berikut kembali penuturan beberapa narasumber mengenai hal diatas:

"Yang paling sering, informasi dari pusat, informasi sekolah-sekolah dipedalaman, bagaimana kita mencari donasi kepada donator-donatur dan Penyesuain diri tidak harus dengan cara tertentu, namun seperti air yang mengalir saja intinya sopan santun saja dalam berbaur dengan sesama anggota". (Andri Munazir,11 Mei 2016).

Penyesuaian dimanapun baik di komunitas maupaun organisasi pasti kita melakukan yang namnya penyesuaian sama orang-orang didalamnya, kalau saya pertama menyesuaikan visi misi Seribu Guru dulu, mau apa Seribu Guru isinya apa aja, aku cocokin visi misi dengan diri sendiri baru setelah itu menyesuaikan diri dengan lingkungan sekitar, dengan orang-orang yang ada di dalam situ, kalau penyesuaian awalnya agak sulit karena menyatukan banyak kepala di gabungin jadi satu, sekarang sudah lumayan enak karena sudah lama bergabung mengetahui 
kekurangan dan kelebihan dari masing-masing tim Seribu Guru. (Sayed Rustia, 10 Mei 2016)

Namanya kita orang baru, bertemu dengan orang, membutuhkan proses, jadi kurang lebih beberapa bulanlah kita melakukan penyesuain diri dan alhamdullah kita sudah seperti saudara sendiri karena mereka kompak. (Fidya Rizkina, 9 Mei 2016).

\section{e. Konflik dan hal positif lainya.}

Konflik yang terjadi dalam komunitas, antar sesama anggota juga menjadi pererat hubungan sesama anggota dalam menjaga hubungan yang baik dikomunitas, konflik juga digunakan sebagai ajang untuk intropeksi diri bagi yang sedang konflik maupun untuk anggota lainya yang tidak berkonflik serta belajar penyelesaian suatu masalah dengan baik. Selanjutnya hal positif yang sudah dirasakan oleh anggota komunitas ini mengenai perubahan diri selama bergabung di komunitas untuk menjadi pribadi yang peduli pada lingkungan sekitar dan pendidikan, apa yang dapat kita berikan untuk bangsa dan negara, bukan menuntut pemerintah. Berikut beberapa penuturan terkait hal diatas:

Konflik itu kami akan menyelesaikan misalnya perorangan itu saya panggil dulu saya tanya dulu apa masalnya setelah itu di bawa ke forum nanti setelah semuanya selesai (Andri Munazir,11 Mei 2016)

Kalau misalnya ada yang konflik kita harus musyawarah, diskusi, karena tidak mungkin kita simpan saja, dan disini di komunitas Seribu Guru Aceh itu sifatnya terbuka tidak ada sesuatu yang di sembunyikan kalau misalnya ada yang bermasalah itu diselesaikan bareng-bareng tidak cuma satu pihak, tidak boleh ada satu pihak memendam masalah sendiri, karena tim saling membantu. (Sayed Rustia, $10 \mathrm{Mei}$ 2016)

Kalau punya salah tidak harus di depan orang kita kritik, atau jumpain dan cat langsung dengan orangnya bertanya langsung dengan orangnya, kalau sudah masalahnya besar maka baru dibawa ke forum. (Khairul Badriah, 13 Mei 2016).

Hal positif belajar dan bekerja tim, meningkatkan jiwa sosial, belajar menyelenggarakan sebuah event. (Rivana Amelia, 12 Mei 2016).

Hal positif yang di dapatkan itu banyak, dari mulai semangat anak-anak di pedalaman lebih banyak dari pada orang-orang dikota selalu banyak mengeluhnya, pendidikan dipedalaman yang seharusnya dilihat berbeda sementara dikota sudah 
banyak yang urusin, melatih kesabaran, manajeman waktu yang paling penting untuk mengatur posisi, jika sedang rapat dalam komunitas maka serius namun kalau diluar dari itu kita teman, banyak hal positif yang kita dapat jika kita mau memcoba dunia baru. (Khairul Badriah, 13 Mei 2016).

Lebih mengurangi melihat adik-adik di pedalamanmereka punya harapan itu kita sebagai generasi muda kalau bukan kita siapa lagi dan kalau bukan sekarang kapan lagi katanya. Jadi kalau hal-halnya itu banyak didapat dari Seribu Gurumisalnya lebih meningkatkan publik speaking, punya rasa kebersamaan dimana saling tengang rasa sesaman anggota tim, tidak mengendepan egois. (Sayed Rustia, 10 Mei 2016).

Hubungan yang terjalin antara anggota dan volunteer sangat baik, komunikasi antara volunteer yang sudah pernah mengikuti kegiatan komunitas dengan anggota tim inti tetap terjalin baik secara tatap muka maupun melalui media sosial, saat ini juga komunitas sedang belajar memperbaiki kekurangan-kekurangan dari setiap kegiatan komunitasnya, seperti halnya saat Travelling and Teachin gpertama adanya kesalahpahaman antara volunteer dengan anggota, namun hal ini juga dilatar belakangi oleh komunitas yang masih baru ada di Aceh dan menyelenggarakan kegiatan travelling and teaching yang pertama, tentunya komunitas masih harus belajar lebih banyak lagi. Namun sudah dapat terlihat kedekatan antara anggota tim inti dengan volunteer, menyatu sesama anggota ditambah lagi dengan rasa memiliki, kepercayaam, kebersamaan yang dibangun agar dapat merelasiasikan tujuan dari komunitas itu sendiri bahkan beberapa di antara mereka, sudah seperti keluarga, faktor-faktor inilah yang menjadi tolak ukur komunitas dalam menjaga hubungan selama ini agar komunikasi tetap berjalan dengan baik diantara anggota maupun volunteer komunitas tersebut.

Peneliti mengamati bahwa, anggota komunitas maupun volunteer sudah terbiasa dengan kerja tim, kompak serta penyesuaian diri yang anggota lakukan juga tidak sulit umunya anggota-anggota dan volunteer telah memiliki pengalaman di organisasi lain dan komunitas lain sebelum bergabung dengan Komunitas Seribu Guru Aceh dan tidak memiliki 
hambatan apapun dalam komunikasi kelompok yang berlangsung diantara anggota dan volunteer. (Darsussalam, 7-13 Mei 2016).

\section{Komunikasi kelompok dalam membentuk konsep diri}

Hasil wawancara dan pengamatan peneliti, hampir keseluruhan informan memiliki jawaban tersendiri mengenai proses komunikasi kelompok terhadap kemampuan diri sendiri dalam mengatasi masalah, mengembangkan diri, pesimis terhadap kompetisi, serta memiliki sikap sangat kritis. Dalam membentuk konsep diri anggota melalui komunikasi kelompok tersebut setiap anggota komunitas saat ditanyai mengenai hal tersebut ada yang mengatakan hal tersebut pernah terpikiran oleh salah satu anggota tersebut namun balik lagi, menyamakan visi dan misi kembali dengan visi misi Seribu Guru Aceh, ada beberapa informan bahwa mengatakan komunikasi kelompok tersebut mampu untuk hal-hal tersebut namun untuk pertanyaan mengenai apakah pesimis terhadap kompetensi memiliki sikap sangat kritis, tergantung pada situasi dan kondisi yang sedang dihadapi.

Berikut penuturan beberapa narasumber terkait hal tersebut:

Ya di Seribu Guru kita di kasih kepercayaan bahwa kita diri kita mampu dan tanggung jawab misalnya tugasnya rental mobil ya, kepercayaan yang di bangun kamu personal mampu bertanggung jawab walau ada masalah kecil. Ya, kita yang menawarkan diri kepada kita punya ketua bidang yang memang kontrol kita dan kita juga punya pekerjaan sendiri dan itu tanggung jawab kita. Tidak, awalnya pesimis awal bergabung karena mereka sangat aktif dan mereka sudah banyak linklink, awalnya pesimis terhadap itu namun karena mereka selalu mendorong ya kamu bisa. Tidak, karena mereka saling menyemanggati. Ya kita harus kritis kalau kita mau mencapai tujuan kita, misalnya ini kemarin memang yang kak terasa kali mengenai audiensi ke KNPI sudah kita coba follow up, sudah berusaha walau pun kita belum berhasil. (Ismita Husna,9 Mei 2016)

Ada sih pasti yang merasakan seperti itu tapi kan balik lagi karena komunitas kan merangkul semua anggota. Ada sih, Kita memberikan kebebasan kepada semua anggota bahwa kita tidak berkontribusi kasih tahu alasanya sebenarnya kita tidak ada yangg di kucilkan, kembali lagi ke tekanan tadi ketika tekananya keras dan tidak menerima akhirnya dia merasa kenapa saya yang di sudutkan padahal sudah jelas kita komunitas tekanan tinggi solusinya dia memberi tahu dan kita saling membantu. Ya pasti, sikap kritis kadang-kadang jika ketua salah, kita memang selalu mencari 
pendapat dan solusi-solusi yang diberikan jadilah kita mengambil kesimpulan. (Erlina Mariana, 7 Mei 2016)

Ya, yakin dengan cara misalnya musyawarah, di Seribu Guru Aceh saya terkendal komunikasi namun bisa belajar di Komunitas Seribu Guru Aceh. Mampu banyak belajar dengan komunikasi dengan mereka yang bisa. Tidak merasa pesimis.Juga tidak merasa cenderung tidak disukai karena mereka saling mendukung.Ya, kiat cepat tanggap dan menyelesaikan misalnya masalah. (Andri Munazir,11 Mei 2016

Ya yakin, itu modal utama di dalam suatu komunitas itu yakin, kalau kita itu bisa kemampuan diri sendiri mengatasi masalah, kalau saya masih belajar ikut Seribu Guru juga mau cari pembelajaraan pertama komunikasinya agak susah komunikasi di Seribu Guru Aceh yang bergabung bukan seumuran dengan kita tapi di Seribu Guru Aceh ada yang sudah bekerja. Sudah banyak pengalamanya, tidak sembarangan berkomunikasi harus memiliki tenggang rasa yang tinggi kemampuan diri sendiri makin terasa. Perkembangan diri dan rasa kepedulian juga meningkat. Ini pernah terjadi sama saya, pernah disuatu titik saya merasa kurang percaya diri karena kurang kontribusi, karena waktu juga, kalau lagi sibuk maka agak pasif ketinggalan informasi itu sih bikin pesimis, pernah terjadi setelah itu. Tidak karena balik lagi, saya lebih mengutamakan visi misi Seribu guru Aceh di bandingkan sikap negatif orang-orangya. Sangat, kalau sikap kritis pasti ada, namanya kita tukar pikiran, mislanya ada masalah pendidikan disini kurang perhatian dari pemerintah na dari situlah dilatih pikiran kritis, dimana pun seharusnya memiliki sikap kritis untuk menghadapi masalah, sikap kritis itu berhubungan erat dengan tingkat kepedulian kita. (Sayed Rustia, 10 Mei 2016)

Peneliti melihat bahwa komunikasi kelompok dalam komunitas ini, dapat membentuk konsep diri masing-masing anggotanya. Informan penelitian mengemukakan bahwa anggota komunitas tersebut memiliki perubahan dalam diri anggota masing-masing hal ini di dukung dengan, adanya annggota komunitas yang telah mendapatkan beberapa hal positif yang mendorong kemampuan individu yaitu mampu mengatasi masalah yang sedang di hadapi, bersyukur, dan mampu menempatkan diri pada tempatnya, belajar mengenai manajemen waktu dengan baik, memiliki banyak teman baru, bertambahnya pengalaman dan wawasan, serta juga belajar mengenai sifat dan karakter orang lain, lebih menghargai orang lain, meningkatkan rasa kepedulian antara sesama dan lingkungan 
sekitar, mampu untuk tidak mengedepan egois, mengembangkan diri yang telah di dapatkan selama bergabung dengan komunitas ini, namun ada juga yang saat bergabung dengan komunitas ini telah memiliki hal positif tersebut.

Sepenuhnya informan mengemukakan bahwa apa yang mereka dapatkan setelah bergabung dengan komunitas ini, masih banyak hal yang harus di perbaiki baik dari diri pribadi anggota komunitas maupun untuk perbaikan masalah komunitas. Seiring dengan berjalanya waktu saat ini komunitas tersebut telah mulai memberikan kontribusi yang baik untuk para anggotanya maupun masyarakat dan anak-anak yang berada di pedalaman yang harus di perhatikan khususnya dunia pendidikan di Aceh, agar tidak adanya perbedaan kualitas pendidikan di kota dan di desa. Sesuai dengan tujuan visi dan misi komunitas sebagai pedoman dalam melaksankan semua kegiatan. Peneliti mengamati bahwa dalam pembentukan konsep diri para anggota komunitas bahwa ada anggota yang telah memiiki konsep diri ada juga yang masih mengetahui gambaran tentang dirinya atau konsep diri (Darussalam dan Lampiueng, 7-11 Mei 2016).

\section{Pembahasan}

Kehidupan sosial yang semakin kompleks, seiring dengan perkembangan zaman, usia dan ilmu pengetahuan kita, maka kita juga mulai masuk menjadi anggota kelompok yaitu kelompok sekunder seperti sekolah, lembaga keagamaan, bimbangan belajar, tempat bekerja, dan kelompok-kelompok lainya sesuai dengan minat dan hobi atas keinginan kita masing-masing.

Komunikasi kelompok digunakan untuk saling bertukar informasi, menambah pengetahuan, memperteguh atau mengubah sikap dan perilaku. Kelompok menjadi kerangka rujukan (frame of reference) kita dalam berkomunikasi. Agar dapat disebut kelompok ketika anggota-anggotanya memiliki kesadaran akan ikatan yang sama yang mempersatukan mereka dengan cara menyamakan visi, misi dan tujuan untuk mendapatkan kekompakan yang tetap. Anggota kelompok juga memiliki suatu bentuk 
keyakinan, prinsip atau rasa saling memiliki yang tidak dimiliki oleh yang bukan anggota kelompok tersebut, Pengambilan keputusan dalam kelompok di pengaruhi oleh komunikasi dalam kelompok sesama anggota yang saling bergantung satu sama lainya. Newcomb mendefinisikan kelompok rujukan sebagai kelompok yang digunakan sebagai alat ukur (standard) untuk menilai diri sendiri atau untuk membentuk sikap. Jika anda menggunakan kelompok tersebut sebagai teladan bagaimana harus bersikap, kelompok itu akan menjadi kelompok rujukan positif dan jika anda menggunakannya sebagai teladan bagaimana seharusnya tidak bersikap, kelompok itu menjadi kelompok rujukan negatif. Kelompok yang terikat kepada kita secara nominal adalah kelompok rujukan kita sedangkan yang memberikan kepada kita identifikasi psikologis adalah kelompokrujukan. (Rakhmat, 2007: 145-146)

Setiap anggota yang bergabung didalam Komunitas Seribu Guru Aceh memiliki tujuan yang sama dengan tujuan komunitas itu sendiri, yaitu menyukai dunia pendidikan, menyukai anak-anak, melakukan hal yang bermanfaat saat jalan-jalan, ingin memberikan motivasi dan ilmu yang mereka miliki kepada yang membutuhkan, dan belajar untuk lebih menghargai. Dalam menjaga keutuhan dan kekompakan komunitas melakukan berbagai kegiatan baik tatap muka atau maupun di media sosial dengan tujuan bersilaturahmi serta tetap mendiskusikan kegiatan-kegaitan komunitas. Sedangkan mengenai kelompok rujukan (volunteer) dan kelompok standar (tim inti) tetap juga menjalin komunikasi.

Komunitas ini memiliki peraturan yang harus di taati oleh semua anggota tanpa terkecuali. Keterbukaan diri dan kedekatan sesama anggota komunitas mengenai penilaian mereka terhadap diri dan komunitas tempat mereka bergabung sangat berpengaruh dalam menentukan konsep diri yang mereka miliki dalam komunitas ini. setiap orang memiliki hak dan peranan yang sama sebagai komunikator maupunkomunikannya. 
Menurut Adlerdan Rodman dalam (sendjaja, 2002 :3-5) mengemukakan empat elemen kelompok yaitu interaksi, waktu, ukuran dan tujuan. Elemen yang pertama Interaksi dalam komunikasi kelompok merupakan faktor yang penting, untuk dapat melangsungkan kegiatan dengan baik interaksi dalam kelompok terus dibangun, itu terlihat dari intensitas pertemuan yang mereka lakukan dan belajar bagaimana berkomunikasi yang baik, selanjutnya elemen kedua yaitu mengenai sekumpulan orang yang berinteraksi untuk jangka waktu yang singkat, tidak dapat digolongkan sebagai kelompok. Komunitas ini bukan hanya berinteraksi dengan jangka waktu yang singkat melainkan mereka tetap berkomunkasi baik di sosial media maupun dalam pertemuanpertemuan tetap aktif berkontribusi dalam memberikan pendapat, masukan ide untuk menunjang kegiatan-kegiatan keolompok.

Ketiga mengenai ukuran atau jumlah partisipan dalam komunikasi kelompok tidak ada ukuran yang pasti mengenai jumlah anggota dalam suatu kelompok. Dari penjelasan diatas mengenai ukuran dan jumlah dari suatu perkumpulan atau komunitas tersebut tidak dibatasi berapa jumlah partisipan yang ada dalam kelompok atau komunitas tersebut dan bisa kita katakan bahwa komunitas tersebut universal, saat ini anggota dari komunitas Seribu Guru Aceh sudah mencapai 31 orang dan volunteer yang bergabung sebanyak 110 oran. Elemen terakhir adalah tujuan yang mengandung pengertian bahwa keanggotaan dalam suatu kelompok akan membantu individu yang menjadi anggota kelompok tersebut dapat mewujudkan satu atau lebih tujuannya. bahwa anggota dalam kelompok tersebut di komunitas Seribu Guru Aceh ini memiliki tujuan, visi, misi yang sama dengan semua anggota dan tujuan pribadi dari mereka masing-masing juga sama, hal ini dikarenakan kencintaan mereka terhadap dunia pendidikan, berjalan-jalan sambil mengajarkan ilmu yang mereka miliki kepada adikadik dipedalaman.

Cooley mendefinisikan diri sebagai sesuatu yang dirujuk dalam pembicaraan biasa melalui kata ganti orang pertama tunggal, yaitu "aku" $(I)$, "daku” (me), "milikku” 
(mine), dan "diriku" (myself), cooley berpendapat bahwa konsep diri individu secara signifikan ditentukan oleh apa yang ia pikirkan tentang pikiran orang lain mengenai dirinya, konsep diri adalah pandangan dan perasaan kita tentang diri kita. Seakan-akan kita melihat diri kita di cermin (looking glass self). Konsep diri bukan hanya sekedar gambaran deskriptif, tetapi juga penilaian kita tentang diri kita, meliputi apa yang kita pikirkan dan apa yang kita rasakan tentang diri kita. (Rakhmat 2007:99)

Meskipun lingkungan di mana kita berada dapat memberikan pengaruh yang cukup besar, namun jika kita memiliki konsep diri yang positif saat kita melihat penghargaan diri, perasaan harga diri, serta penerimaan diri yang juga positif, maka atmosfir negatif lingkungan dapat kitahindari. Menurut Charles Horton Cooley, kita melakukannya dengan membayangkan diri kita sebagai orang lain dalam benak kita. Looking-glass self (diri cermin), seakan-akan kita menaruh cermin di depan kita. Pertama, kita membayangkan bagaimana kita tampak pada orang lain, kita melihat sekilas diri kita seperti dalam cermin. Kedua, kita membayangkan bagaimana orang lain menilai penampilan kita. Ketiga, kita mengalami perasaan bangga atau kecewa, orang mungkin merasa sedih atau malu (Vander Zanden 1975: 79 dalam Rakhmat 2007:99).

Dengan mengamati diri kita, sampailah kita pada gambaran dan penilaian diri kita, ini disebut konsep diri anggota komunitas saat di wawancarai mengenai komunikasi kelompok setiap individu menyebutkan bahwa para anggota sering sekali menggunakan sarana ini untuk mengetahui bagaimana sebenarnya peribadi dari masing-masing anggota selama ini, sesuai dengan teori looking glass self (diri cermin), dan juga anggota komunitas baik secara langsung atau tidak belajar banyak hal mengenai dirinya tentunya dengan anggota kelompok lainya, melihat kekurangan dari diri sendiri dan mencoba belajar dengan orang-orang yang mempunyai kelebihan didalam komunitas tersebut, melalui komunikasi kelompok yang terjadi juga pada kegiatan-kegiatan komunitas baik di saat pertemuan ataupun saat dilapangan antara anggota dan volunteer tetap melakukan komunikasi dan koordinasi, beberapa anggota 
komunitas awalnya merupakan volunteer dari komunitas tersebut, namun karena dilihat anggota mempunyai kemampuan untuk melaksanakan tugas dan tanggung jawab, ditambah dengan keberhasilan-keberhasilan anggota tersebut. Adanya perekruttan anggota dari volunteer tersebut.

Anggota komunitas Seribu Guru Aceh juga dibentuk dan dibangun proses mental individu-individu dengan berbagai cara dalam setiap kegiatan mereka seperti mampu berbicara atau berkomunikasi dengan masyarakat, pemerintah dan pejabat negara, bertanggung jawab akan pekerjaan yang diberikan, siap menerima kritik dan saran, saling mengingatkan, memberikan saran serta masukan pada anggota, melengkapi kekurangan anggota komunitas, membantu para anggota memiliki konsep diri untuk menjadi lebih baik tentunya, namun kembali lagi pada anggota-anggota komunitas tersebut untuk mau mendengarkan saran atau tidak, serta komunikasi kelompok tetap terjalin diantara anggota komunitas tersebut.

Dikutip dari Freud (1900) mengungkapkan bahwasanya hal yang terpenting dari diri individu adalah proses mental. Freud mengatakan bahwasanya konsep diri merupakan sebuah unit psikologis yang paling dasar untuk memahami proses mental individu. Dan Roger juga (1947) mencoba untuk mengembangkan pola self dalam sebuah sistem psikologis. Roger menilai bahwa self merupakandasar atau hal utama yang menjadi bagian dari kepribadian dan penyesuaian individu. Roger juga mengatakan bahwasanya selfmerupakan produk sosial yang tumbuh dari proses interpersonal yang dilakukan (Purkey, 1988: 2). Individu-individu yang mengeluarakan produk sosial mereka sesuai dengan konsep diri yan mereka miliki, baik itu konsep diri positif maupun konsep diri negatif.

Keseluruhan anggota saat diwawancarai mengenai kesiapan anggota dalam melakukan kegiatan-kegiatan, anggota sudah siap memang anggota komunitas sendiri sudah memilki jiwa-jiwa sosial, ditambahlagi dengan anggota yang masih baru 
bergabung dalam komunitas bertindak dengan konsep diri yang sudah mereka miliki hal ini juga merupakan hampir keseluruhan anggota yang bergabung sudah memiliki pengalaman-pengalaman terlebih dahulu mengenai bagaimana menyelenggarakan sebuah kegiatan-kegiatan, sedangkan bagi anggota yang baru akan dibantu oleh anggota komunitas lainya, namun ada juga yang dibantu oleh anggota yang baru, intinya adanya saling membantu didalan tim. Benar bahwa konsep diri juga menjadi acuan bagi diri pribadinya masing-masing dan ada pula yang mengajarkan dan membantu para anggatanya untuk memiliki konsep diri yang lebih baik lagi.

Para anggota Komunitas Seribu Guru Aceh umumnya sudah memilki konsep diri positif tidak ada yang negatif, konsep diri yang positif juga mempengaruhi individuindvidu yang ada dalam komunitas tersebut, selama bergabung kemampuankemampuan individu juga mengalami peningkatan, bukan itu saja namun individuindividu juga merasa lebih bersyukur atas kesempatan mereka dapat mengajarkan ilmu yang mereka miliki kepada adik-adik dipedalaman yang belum di samakan kualiats pendidikanya dengan kualitas pendidikan dikota, Selanjutnya Menurut William D. Brooks dan Philip Emmert bahwa tanda-tanda konsep diri terdiri dari dua yaitu konsep diri positif dan negatif. Konsep diri positif ditandai dengan lima hal di antaranya, yakin akan mampu mengatasi masalah, merasa setara dengan orang lain, menerima pujian tanpa rasa malu, menyadari bahwa setiap orang mempunyai berbagai perasaan, keinginan dan perilaku yang tidak seluruhnya disetujui oleh masyarakat, yang terakhir ia mampu memperbaiki dirinya. Adapun konsep diri yang negatif yaitu, peka pada kritik, responsif sekali atas pujian, cenderung merasa tidak disenangi oleh orang lain, dan bersikap pesimis terhadap kompetisi. (Rakhmat, 2007:105).

Mengenai konsep diri negatif yang ditandai dengan ciri-ciri diatas keseluruhan tidak ada namun, dari beberapa anggota menyebutkan bahwa, pernah terpikiran hal tersebut namun, anggota tersebut berpikir kembali dan menayakan pada dirinya apa 
tujuanya dan menyamakan lagi tujuan anggota tersebut dengan tujuan komunitas tersebut.

Hasil penelitian yang di peroleh dalam penelitian ini yaitu komunikasi yang terjadi dan terjalin antara sesama anggota dan volunteerberjalan dengan baik, anggota dan volunteer sudah memilki kedekatan hal ini juga didukung dengan beberapa faktor yaitu komunikasi, menjaga kepercayaan sesama tim, saling menerima kekurangan anggota masing-masing, konflik, penyesuain diri dan berbagi informasi lainya. Sedangkan komunikasi kelompok dalam komunitas dapat membentuk konsep diri anggotnya, konsep diri juga mengarah kepada konsep diri positif yaitu, meningkatkan rasa kepedulian, meningkatkan rasa percaya diri akan kemampuan diri yang dimiliki, memiliki banyak teman, menjadi lebih menghargai orang lain dan meningkatkan kemampuan berkomunkasi dengan baik. Yang terpenting bahwa melalui komunitas Seribu Guru Aceh seluruh anggotamempunyai kemampuan, berbagi ilmu dan pengalaman, kepada anak-anak yang membutuhkan, terutama anak-anak yang berada didaerah pedalaman dalam mengecap pendidikan.

\section{Penutup}

Berdasarkan hasil penelitian dan pembahasan yang telah dilakukan pada bab-bab sebelumnya mengenai komunikasi kelompok dalam membentuk konsep diri anggota Komunitas Seribu Guru Aceh, maka diperoleh kesimpulan sebagai berikut. Komunikasi kelompok yang terjalin dalam Komunitas Seribu Guru Aceh sangat baik, antara sesama anggota maupun dengan volunteer, komunikasi kelompok yang terjalin antara anggota, baik melalui tatap muka dan melalui media sosial, silaturahmi yang terus dijalin bersama volunteer yang sudah pernah menjadi volunteer tetap terjalin begitu juga sebaliknya yang sudah pernah menjadi volunteer juga tetap bersilaturhami dengan anggota tim inti. Komunikasi kelompok yang terjadi dalam membentuk konsep diri anggota komunitas, keseluruhan anggota komunitas sudah memilki konsep diri, yaitu konsep diri positif, hal ini didukung oleh pengalaman-pengalman individu sebelum bergabung dengan Komunitas Seribu Guru Aceh, serta ada juga anggota yang konsep dirinya masih harus di lihat kembali, para anggota yang sudah memilki konsep diri tersebut membantu anggota lainnya. Dan

komuikasi kelompok mampu dalam membentuk konsep diri. 


\section{Daftar Pustaka}

Ali, Mohammad. 2014. Memahami Riset Perilaku dan Sosial. Jakarta: PT Bumi Aksara.

Cangara, Hafid. 2011. Pengantar Ilmu Komunikasi. Jakarta: Raja GrafindoPersada.

Kriyantono, Rakhmat. 2006. Teknik Praktis Riset Komunikasi. Jakarta: Kencana.

Purkey, W., 1988, An Overview Of Self-Concept Theory For Counselors, www.ericdigests.org/pre-9211/self.htm, diakses tanggal 2 Jaunari 2016.

Rakhmat, Jalaludin. 2007. Psikologi Komunikasi. Bandung: PT Remaja Rosdakarya.

Sendjaja, S Djuarsa. 2002. Teori Komunikasi. Jakarta: Pusat Penerbit Universitas Terbuka.

Sugiyono. 2009. Metode Penelitian Kuantitatif dan Kualitatif. Bandung: CV.Alfabeta.

Taher, Alamsyah. 2009. Metode Penelitan Sosial. Banda Aceh: Syiah Kuala University Press.

Tulong Aceh (1 September 2015).1000 Guru Siap Berkontribusi Untuk Pendidikan Diplosok Aceh' Diakses pada 10 Desember 2015 dari <http://tulongaceh.weebly.com/kisahinspiratif/hati>. 